\title{
Dimethyl sulfide, methane sulfonic acid and physicochemical aerosol properties in Atlantic air from the United Kingdom to Halley Bay
}

\author{
Brian Davison, and C. Nicholas Hewitt, \\ Institute of Environmental and Biological Sciences, Lancaster University, Lancaster, United Kingdom
}

Colin D. O'Dowd, Jason A. Lowe, and Michael H. Smith

Department of Pure and Applied Physics, University of Manchester Institute of Science and Technology, Manchester, United Kingdom

Margit Schwikowski and Urs Baltensperger,

Paul Scherrer Institut, Villigen, Switzerland

Roy M. Harrison

Institute of Public and Environmental Health, University of Birmingham, Birmingham, United Kingdom

\begin{abstract}
The concentrations of dimethyl sulfide in air were obtained during a cruise between the United Kingdom and the Antarctic in the period October 1992 to January 1993 using a method of sampling and analysis optimized to avoid interferences from oxidants. In equatorial regions $\left(30^{\circ} \mathrm{N}\right.$ to $\left.30^{\circ} \mathrm{S}\right)$ the atmospheric DMS concentration ranged from 3 to $46 \mathrm{ng}(\mathrm{S}) \mathrm{m}^{-3}$, with an average of $18 \mathrm{ng}(\mathrm{S}) \mathrm{m}^{-3}$. In the polar waters and regions south of the Falkland Islands, concentrations from 3 to $714 \mathrm{ng}(\mathrm{S}) \mathrm{m}^{-3}$ were observed, with a mean concentration of $73 \mathrm{ng}(\mathrm{S}) \mathrm{m}^{-3}$. The concentrations of a range of DMS oxidation products were also obtained. No clear relationships between reactant and product concentrations were seen. Information on particle number concentration, Fuchs surface area and the thermal volatility characteristics of the ambient aerosol was obtained, but again no clear relationships with sulfur concentrations were observed. Accumulation mode particle concentrations averaged $25 \mathrm{~cm}^{-3}$ in the clean marine and polar air masses south of $58^{\circ} \mathrm{S}$ while background condensation nuclei (CN) concentrations were of the order of $400-600 \mathrm{~cm}^{-3}$. Simplistic calculations suggest that a particle source strength of about $20-60$ particles $\mathrm{cm}^{-3} \mathrm{~d}^{-1}$ is required to sustain this background $\mathrm{CN}$ concentration. It is not clear whether boundary layer nucleation of new $\mathrm{CN}$ or entrainment from the free troposphere provided the source of $\mathrm{CN}$. Periods of elevated $\mathrm{CN}$ concentrations $\left(>4000 \mathrm{~cm}^{-3}\right)$ were regularly observed in the boundary layer over the Weddell Sea and were attributed to "bursts" of new particle formation. However, shortly after these nucleation events the $\mathrm{CN}$ concentration rapidly decayed to the background level through coagulation losses, suggesting little impact on the background $\mathrm{CN}$ or cloud condensation nuclei $(\mathrm{CCN})$ concentration.
\end{abstract}

\section{Introduction}

There is considerable current interest in attempting to understand what controls the cloudiness of the Earth over both oceanic and continental regions, since the degree of cloud cover directly affects the albedo, and hence the radiation balance, of the globe. Dimethyl sulfide, produced by the metabolism of marine phytoplankton and emitted into the atmosphere as a result of its very appreciable concentration gradient across the water-air interface [Liss and Slater, 1974], is oxidized in the atmosphere to give a variety of gas and aerosol phase products [e.g., Yin et al., 1990a; b; Davison and Hewitt, 1992; 1994]. It has been speculated that some of these products may be important sources of cloud condensation nuclei (CCN) in oceanic areas [Charlson et al., 1987]. One of these products is likely to be methane sulfonic acid (MSA) and, indeed, a significant seasonal relationship between $\mathrm{CCN}$ and MSA concentrations has been observed in remote maritime air [Ayers and Gras, 1991]. However, establishment of a causal relationship among DMS emissions, aerosol number concentration, and cloudiness has not been established [ Hegg,

Copyright 1996 by the American Geophysical Union.

Paper number 96JD01166.

0148-0227/96/96JD-01166\$09 00
1990; Raes and Van Dingenen, 1992]. In addition, aerosol particles themselves have direct and indirect interactions with solar and terrestrial radiation and so may modify the planetary radiation balance by the processes of scattering and absorption [Coakley et al., 1983; Charlson et al., 1992; Fouquart and Isaka, 1992].

Here we report on the concentrations of DMS, MSA, nonsea-salt sulfate (nssS), particle number concentration, and Fuchs surface area of the ambient aerosol measured along a transect through the Atlantic Ocean from the United Kingdom to Halley Bay in Antarctica.

\section{Experimental Methods}

\section{Dimethyl Sulfide}

Gas phase dimethyl sulfide (DMS) present in the atmosphere was preconcentrated by passing a known volume of air through a tube containing molecular sieve $5 \mathrm{~A}$, with a potassium iodide (KI) crystal oxidant scrubber. Details of the experiments used to characterize molecular sieve as the optimum sampling media and KI crystals as the optimum oxidant scrubber are described by Davison and Allen [1994]. A permeation tube (VICI Metronics) held at a constant temperature $\left(30^{\circ} \pm 0.1^{\circ} \mathrm{C}\right)$ was used as a source of gas phase 
DMS (10 $\mathrm{ng}(\mathrm{S}) \mathrm{min}^{-1}$ ) into purified nitrogen carrier gas for concentrating onto tubes containing molecular sieve 5A for calibration purposes. Nafion tubing immersed in molecular sieve 5A (International Scientific Consultants and PermaPure Products) was used upstream of the collection matrix and scrubber to selectively remove water vapor from the sample stream.

A Hewlett Packard 5890A gas chromatograph fitted with a flame photometric detector and a $4 \mathrm{~m} \times 0.125 \mathrm{~cm}$ Teflon column containing Chromosil 330 was used as the analytical system. Gas flows were $35 \mathrm{~mL} \mathrm{~min}$ me carrier), $100 \mathrm{~mL} \mathrm{~min}^{-1}$ (air supply to burner) and $75 \mathrm{~mL} \mathrm{~min}^{-1}\left(\mathrm{H}_{2}\right.$ supply to burner). An oxygen trap (Phase Sep) was placed in the helium line, and all gases passed through molecular sieve 13X. An oven temperature of $65^{\circ} \mathrm{C}$ was used with a detector temperature of $230^{\circ} \mathrm{C}$. Sample tubes were desorbed at $280^{\circ} \mathrm{C}$ using an analysis automation desorption oven. A $20 \mathrm{ppmv}$ mixture of carbonyl sulfide (COS) in nitrogen was continuously introduced to the detector at a rate of $\ll 1 \mathrm{~mL} \mathrm{~min} \mathrm{~m}^{-1}$, in order to increase sensitivity and permit detection of $-0.2 \mathrm{ng}(\mathrm{S})$ of DMS (equivalent to $14 \mathrm{pptv}$ of DMS for a $10 \mathrm{~L}$ air sample) [Goldan et al., 1987].

The method allowed DMS to be quantitatively sampled with a time resolution of 2-3 hours, with a detection limit of 10 pptv, and an analytical precision and accuracy of $\pm 5 \%$ without the need for cryogenic liquids and without losses due to oxidation by ozone.

\section{Methane Sulfonic Acid and Other Ionic Species}

Methane sulfonic acid (MSA), sulfate, chloride, and a range of cations, including sodium, magnesium, calcium, and potassium, in the ambient aerosol were obtained by highvolume sampling through prewashed Whatman QMA quartz fiber filters at $0.7 \pm 0.05 \mathrm{~m}^{3} \mathrm{~min}^{-1}$ with sampling periods of 24 hours. Samples were extracted into Milli-Q water and analyzed by ion chromatography using an AS4-A column for anions and a CS12-A column for cations on a Dionex $4000 \mathrm{i}$ instrument [Davison and Hewitt, 1992]. Blank filters underwent the same procedure as for samples but without the passage of air and were collected periodically during the cruise. Detection limits of about $1 \mathrm{nmol} \mathrm{m}^{-3}$ for $\mathrm{Cl}^{-}$and $\mathrm{NO}_{3}^{-}$and $0.3 \mathrm{nmol} \mathrm{m}^{-3}$ for $\mathrm{SO}_{4}{ }^{2-}$ were found. Experimental precision was $8 \%$ for MSA and $\mathrm{NO}_{3}{ }^{-}$ and $<5 \%$ for all other species. Sodium concentrations were also obtained by flame photometry.

\section{Sulfur Dioxide}

Sulfur dioxide was collected from air using rigourously prewashed Whatman 54 filters impregnated with a solution of $5 \mathrm{~g} \mathrm{~K}_{2} \mathrm{CO}_{3}$ and $10 \mathrm{~mL}$ glycerol (Fluka Ultrapure) in $100 \mathrm{~mL}$ Milli-Q water [Ferek et al., 1991]. The filters were prewashed by leaching for 3 days with water changed daily and rinsing in Milli-Q water prior to drying in a clean room and filtered laminar-flow environment. Clean filters were stored in double polythene bags. The filters for $\mathrm{SO}_{2}$ sampling were treated with the carbonate/glycerol mixture 24 hours before use and dried in a desiccator prior to use. A $0.45-\mu \mathrm{m}$ Teflon membrane was used as a front filter to remove particulate sulfate already present in the atmosphere, and the gascous $\mathrm{SO}_{2}$ was retained as sulfite $\left(\mathrm{SO}_{3}{ }^{2-}\right)$ on the second filter. A flow rate of $16 \mathrm{dm}^{3} \mathrm{~min}^{-1}$ was used and samples were collected concurrently with those of DMS. Sulfate was removed from the front filter by ultrasonic extraction in $20 \mathrm{~mL}$ Milli- $Q$ water and the impregnated filters were extracted in the same manner. After shaking, $0.1 \mathrm{~mL}$ hydrogen peroxide $(30 \% \mathrm{w} / \mathrm{v})$ was added to a $5 \mathrm{~mL}$ aliquot of the latter solution to assure complete oxidation to $\mathrm{SO}_{4}{ }^{2-}$ before analysis by ion chromatography. A detection limit of $50 \mathrm{ng}(\mathrm{S})$ $\mathrm{m}^{-3}$ was calculated for $\mathrm{SO}_{2}$ assuming a 3-hour sampling time.

\section{Aerosol Characteristles}

A TSI 3025 ultrafine condensation particle counter (TSI, St. Paul, Minnesota) was used to measure the number concentration of the ambient aerosol every $15 \mathrm{~min}$ in the size range $3 \mathrm{~nm}$ $5 \mu \mathrm{m}$ diameter.

The Fuchs surface area of the ambient aerosol was determined with an epiphaniometer. This instrument is described in detail by Gäggeler et al. [1989] and its use in clean continental air by Baltensperger et al. [1991]. Briefly, ambient air is pumped through a chamber containing atoms of ${ }^{211} \mathrm{~Pb}$, generated at a constant rate by the decay of the short-lived isotope ${ }^{219} \mathrm{Rn}$, itself produced by the decay of ${ }^{227} \mathrm{Ac}$. The ${ }^{211} \mathrm{~Pb}$ atoms rapidly attach to aerosol particles and are carried through a capillary and deposited on a filter, while lighter unattached ${ }^{211} \mathrm{~Pb}$ atoms diffuse rapidly to the capillary walls. The resultant activity on the filter is measured continuously by a surface barrier detector. This signal, reported in terms of counts per second, is proportional to the Fuchs surface area of the sampled aerosol [Pandis et al., 1991].

Information on the chemical composition of the ambient aerosol was obtained with a thermal analytical or volatility technique. This method has previously been described by O'Dowd et al. [1992]. It consists of a heated quartz inlet tube in front of a Particle Measuring Systems ASASP-X optical particle counter. The inflowing air is heated to $1050^{\circ} \mathrm{C}$, causing fractions of the ambient aerosol to evaporate at specific, characteristic, temperatures and thus allows inference of chemical composition. Among the chemical species that can be identified with this method are sulfuric acid, ammonium sulfate/bisulfate, sea salt, and soot carbon. The size range of the particles detected with this instrument is $0.1-3 \mu \mathrm{m}$ diameter. Ambient, or non volatilized, aerosol characteristics measured by the ASASP-X through the volatility system are measured at about $30^{\circ} \mathrm{C}$ above ambient temperatures before being subjected to volatilization and thus represent a dry aerosol size which is independent of relative humidity [ $O^{\prime} D$ owd et al., 1993].

\section{Measurement Program}

Measurements were made onboard the RRS Bransfield during the period October 2, 1992, to January 14, 1993. The Bransfield is a supply ship that services the British Antarctic Survey bases in Antarctica. The cruise consisted of five legs: (1) from Grimsby in the United Kingdom to Montevideo, Uruguay (October 26, 1992, Julian days 276-300); (2) Montevideo to Port Stanley in the Falkland Islands (October 29, - November 1, 1992, Julian days 303-306); (3) Port Stanley to Faraday Base on the Antarctic Peninsula at $65^{\circ} 15^{\prime} \mathrm{S}$, $64^{\circ} 16^{\prime} \mathrm{W}$ and back to Port Stanley (November 4, - November 14, 1992, Julian days 310-319); (4) a repeat passage to Faraday and back (November 18, - December 12, 1992, Julian days 323-339); and finally (5) Port Stanley to Halley Bay at $75^{\circ} 35^{\prime} \mathrm{S}, 26^{\circ} 46^{\prime} \mathrm{W}$ in the east Weddell Sea and back to Port Stanley (December 7, 1992 - January 14, 1993, Julian days 342-380). 


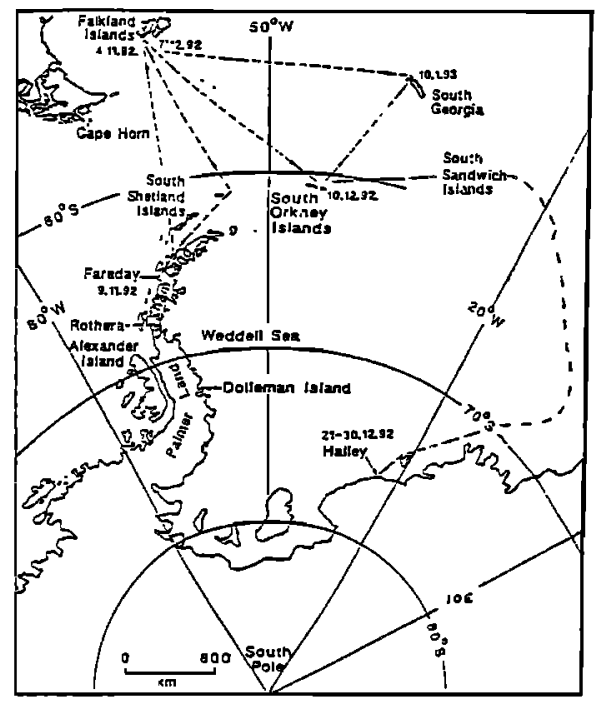

Figure 1. Route of the RRS Bransfield from the Falkland Islands to Antarctica November 4, 1992, to January 10, 1993.

The period December 21 to 30, 1992, was spent at Halley Bay Base. The southern portion of the cruise track is shown in Figure 1. For ease of presentation of the data, January 1, 1993, has been designated as Julian day 367 .

Air sampling systems were housed in a cabinet on the monkey deck of the ship at a height of $20 \mathrm{~m}$ above the sea surface in front of the ship's stack. Wind speed and direction were logged at this location at 3-min intervals and this information, together with nitrogen dioxide concentrations obtained with a Scintrex luminol detector, used to identify periods of time when contamination from the ship's emissions were likely to have occurred. Data from these periods are excluded from the presentation and discussion here.

\section{Results and Discussion}

\section{Dimethyl Sulfide}

The concentrations of DMS measured during the cruise are shown with latitude in Figure 2 and are summarized in Tables 1 - 3. Very low DMS concentrations $\left(3-46 \mathrm{ng}(\mathrm{S}) \mathrm{m}^{-3}\right)$ were observed through the North and South Atlantic as far south as $58^{\circ}$, with an average of $18 \mathrm{ng}(\mathrm{S}) \mathrm{m}^{-3}$. This is consistent with low biological activity during the northern hemisphere winter and in the open ocean waters of the southern hemisphere. Farther south, much higher concentrations were observed: a mean DMS concentration of $40 \mathrm{ng}(S) \mathrm{m}^{-3}$ was found in samples collected during the passage to the British Antarctic Survey's Faraday Base during November 1992, with a higher mean concentration of $102 \mathrm{ng}(S) \mathrm{m}^{-3}$ observed in the Weddell Sea during the passage to Halley Bay. Extreme DMS concentrations

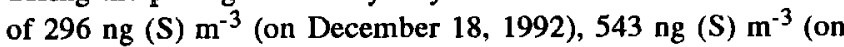
December 20, 1992), and $382 \mathrm{ng}(S) \mathrm{m}^{-3}$ (on December 21, 1992) were observed when in broken sea ice and along the front of the polar ice shelf in the area $67^{\circ}-74^{\circ} \mathrm{S}$.

These data are broadly consistent with those previously obtained in these regions by Berresheim [1987], Staubes and Georgii [1993], and Kirst et al. [1993] and with the observations of spring, summer, and autumn phytoplankton blooms in the vicinity of the Antarctic Peninsula [Krebs, 1983; Leakey, 1991]. Sea ice is believed to offer an ideal

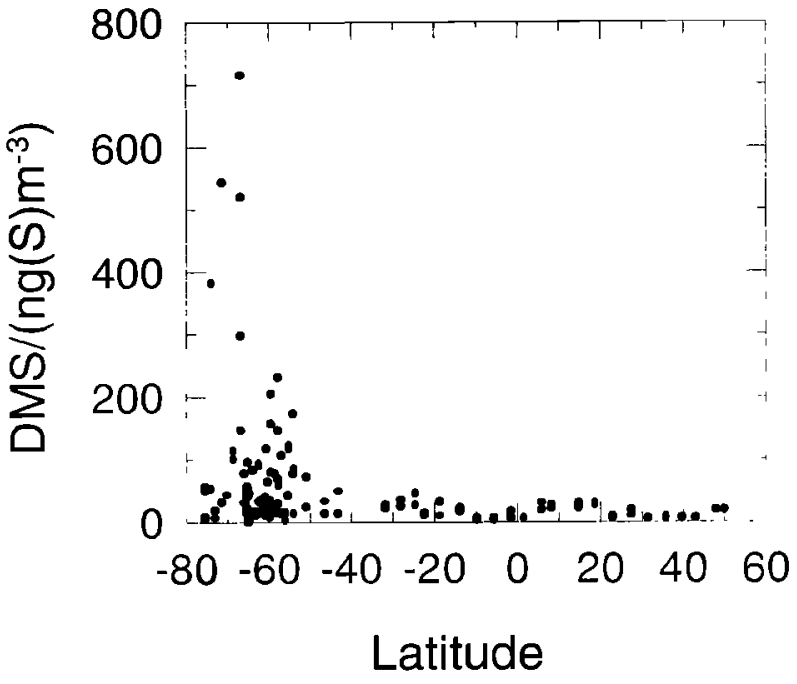

Figure 2. Concentrations of dimethyl sulfide in air with latitude during the cruise of RRS Bransfield October 2, 1992, to January 10, 1993.

habitat for phytoplankton growth [Bunt, 1968] and, indeed, an orange/brown discoloration was observed on the underside of the sea ice during the passage to Halley Bay. Open water and broken sea ice allow the exchange of gas between the seawater and the overlying air, but extensive or complete coverage of the sea by ice will cause a significant reduction in gas transfer, leading to lower DMS concentrations in air.

Simplistically, a dependence between DMS concentrations in air and both the wind speed and the height of the atmospheric boundary layer might be expected, with high wind speeds enhancing the water-air flux rate [Liss and Slater, 1974] and an increasing boundary layer height leading to a dilution of DMS in the atmosphere. However, a very poor correlation $\left(r^{2}=\right.$ 0.14 ) was found between wind speed and DMS concentrations. This is not surprising since the measurements were made from a ship moving through areas of varying DMS production rates. Insufficient meteorological data were available for a correlation between boundary layer height and DMS concentration to be made.

\section{Methane Sulfonic Acid}

The concentrations of MSA observed during the cruise are shown in Figure 3 (against latitude). The data are summarized in Tables 1-3. Very low concentrations were observed from the United Kingdom through the Atlantic to $58^{\circ} \mathrm{S}$ (mean of $14 \mathrm{ng}$ $\mathrm{m}^{-3}$ ), with much higher concentrations measured in the vicinity of the Antarctic Peninsula and in the Weddell Sea (mean $103 \mathrm{ng}$ $\left.m^{-3}\right)$.

Some broad agreement was seen between DMS and MSA concentrations, with periods of enhanced DMS and MSA concentrations coinciding. This is consistent with the belief that MSA is produced by the oxidation of DMS in the troposphere by, principally, the hydroxyl radical $(\mathrm{OH})$ during the day and the nitrate radical $\left(\mathrm{NO}_{3}\right)$ at nighttime. However, the linear regression of individual DMS and MSA concentrations gave a very poor correlation $\left(r^{2}=0.3\right)$. This poor correlation might be expected given the inhomogeneous spatial nature of DMS production from phytoplankton and its flux into the atmosphere, the variable lifetime of DMS in the atmosphere (which depends on the oxidant concentration), the transport of 
Table 1. Concentrations of Chemical Species in Air Determined During the Entire Cruise of the RRS Bransfield From the United Kingdom to Antarctica October 3, 1992, to January 10, 1993

\begin{tabular}{lllll}
\hline Species & Mean & Maximum & Minimum & $n$ \\
\hline $\mathrm{DMS} / \mathrm{ng}(\mathrm{S}) / \mathrm{m}^{3}$ & 54 & 714 & 0 & 140 \\
$\mathrm{Cl} / \mu \mathrm{g} / \mathrm{m}^{3}$ & 8.2 & 35 & 0.1 & 65 \\
$\mathrm{NO}_{3}-\mu \mathrm{g} / \mathrm{m}^{3}$ & 0.8 & 12 & 0.01 & 34 \\
$\mathrm{SO}_{4}{ }^{2-} / \mu \mathrm{g} / \mathrm{m}^{3}$ & 3.0 & 16 & 0.36 & 67 \\
$\mathrm{nssS}^{3} \mu \mathrm{g} / \mathrm{m}^{3}$ & 0.8 & 4.0 & 0.06 & 47 \\
$\mathrm{Na}^{+}(\mathrm{FP}) / \mu \mathrm{g} / \mathrm{m}^{3}$ & 6.8 & 29.8 & 0.17 & 64 \\
$\mathrm{Na}^{+}(\mathrm{IC}) / \mu \mathrm{g} / \mathrm{m}^{3}$ & 5.5 & 14.5 & 0.25 & 56 \\
$\mathrm{MSA} / \mathrm{ng} / \mathrm{m}^{3}$ & 77 & 362 & 1.72 & 62 \\
$\mathrm{MSA} / \mathrm{nssS}$ & 0.16 & 1.1 & $<0.01$ & 49 \\
$\mathrm{NH}_{4}{ }^{+} / \mu \mathrm{g} / \mathrm{m}^{3}$ & 0.86 & 10.1 & 0.01 & 45 \\
$\mathrm{~K}^{+} / \mu \mathrm{g} / \mathrm{m}^{3}$ & 0.33 & 5.6 & 0.01 & 52 \\
$\mathrm{Mg}^{2+} / \mu \mathrm{g} / \mathrm{m}^{3}$ & 0.82 & 4.9 & 0.003 & 63 \\
$\mathrm{Ca}^{2+} / \mu \mathrm{g} / \mathrm{m}^{3}$ & 0.33 & 1.6 & 0.01 & 60 \\
$\mathrm{SO}_{2} / \mathrm{ng} / \mathrm{m}^{3}$ & 804 & 1593 & 95.9 & 50 \\
\hline
\end{tabular}

DMS and its oxidation products from source regions by advection to the moving measurement station, and the different atmospheric lifetimes of the gas phase primary reactant and its aerosol phase product.

\section{Non-Sea-Salt Sulfate and Sulfur Dloxide}

Figure 4 shows the concentrations of non-sea-salt sulfate (nssS) (calculated using $\mathrm{Na}^{+}$as a tracer of sea salt) measured with latitude. In the first, northern, part of the cruise a mean concentration of $1.1 \mu \mathrm{g} \mathrm{m}^{-3}$ (range $0.06-4.03 \mu \mathrm{g} \mathrm{m}^{-3}$ ) was observed. Northerly winds causing contamination of samples were encountered while crossing the Bay of Biscay. These concentrations are rather higher than the observations of $R$. M. Harrison et al., (personal communication, 1996), and in the vicinity of the Azores and of Luria et al. [1989] in the vicinity of Bermuda, possibly due to the long-range transport of anthropogenic sulfur-dioxide-derived sulfate from continental areas, emissions of which are enhanced during the winter (the measurements of $\mathbf{R}$. M. Harrison et al. and Luria et al. having

Table 2. Concentrations of Chemical Species in Air Determined During the Northern Part of the Cruise of the RRS Bransfield From the United Kingdom to the Falkland Islands October 3, 1992 to November 1, 1992

\begin{tabular}{lcccc}
\hline \multicolumn{1}{c}{ Species } & Mean & Maximum & Minimum & $n$ \\
\hline $\mathrm{DMS} / \mathrm{ng}(\mathrm{S}) / \mathrm{m}^{3}$ & 18 & 47 & 2.8 & 48 \\
$\mathrm{Cl} / \mu \mathrm{g} / \mathrm{m}^{3}$ & 8.9 & 19.6 & 1.2 & 22 \\
$\mathrm{NO}_{3}-/ \mu \mathrm{gg} / \mathrm{m}^{3}$ & 1.2 & 12.0 & 0.03 & 20 \\
$\mathrm{SO}_{4}{ }^{2-} / \mu \mathrm{g} / \mathrm{m}^{3}$ & 4.6 & 14.7 & 1.33 & 22 \\
$\mathrm{nssS} / \mu \mathrm{g} / \mathrm{m}^{3}$ & 1.13 & 4.0 & 0.06 & 17 \\
$\mathrm{Na}^{+}(\mathrm{FP}) / \mu \mathrm{g} / \mathrm{m}^{3}$ & 9.0 & 27.8 & 2.34 & 22 \\
$\mathrm{Na}^{+}(\mathrm{IC}) / \mu \mathrm{g} / \mathrm{m}^{3}$ & 7.5 & 14.5 & 1.93 & 21 \\
$\mathrm{MSA} / \mathrm{ng} / \mathrm{m}^{3}$ & 14.3 & 39.7 & 1.72 & 18 \\
$\mathrm{MSA} / \mathrm{nssS}$ & 0.026 & 0.29 & 0.002 & 18 \\
$\mathrm{NH}_{4}{ }^{+} / \mu \mathrm{g} / \mathrm{m}^{3}$ & 2.8 & 10.1 & 0.09 & 10 \\
$\mathrm{~K}^{+} / \mu \mathrm{g} / \mathrm{m}^{3}$ & 0.3 & 0.7 & 0.11 & 20 \\
$\mathrm{Mg}^{2+} / \mu \mathrm{g} / \mathrm{m}^{3}$ & 0.9 & 1.7 & 0.22 & 20 \\
$\mathrm{Ca}^{2+} / \mu \mathrm{g} / \mathrm{m}^{3}$ & 0.44 & 1.6 & 0.08 & 20 \\
$\mathrm{SO}_{2} / \mathrm{ng} / \mathrm{m}^{3}$ & 913 & 1562 & 95.9 & 19 \\
\hline
\end{tabular}


Table 3. Concentrations of Chemical Species in Air Determined During All Legs of the Cruise of the RRS Bransfield South of the Falkland Islands November 5, 1992 to January 10, 1993

\begin{tabular}{|c|c|c|c|c|}
\hline Species & Mean & Maximum & Minimum & $n$ \\
\hline DMS/ng $(\mathbf{S}) / \mathrm{m}^{3}$ & 73 & 714 & $<$ d.l. & 92 \\
\hline $\mathrm{Cl}^{-} / \mu \mathrm{g} / \mathrm{m}^{3}$ & 7.9 & 35 & 0.1 & 43 \\
\hline $\mathrm{NO}_{3}-/ \mu \mathrm{g} / \mathrm{m}^{3}$ & 0.2 & 0.74 & 0.01 & 13 \\
\hline $\mathrm{SO}_{4}^{2-} / \mu \mathrm{g} / \mathrm{m}^{3}$ & 2.2 & 15.8 & 0.36 & 45 \\
\hline $\mathrm{nss} S / \mu \mathrm{g} / \mathrm{m}^{3}$ & 0.5 & 1.83 & 0.08 & 30 \\
\hline $\mathrm{Na}^{+}(\mathrm{FP}) / \mu \mathrm{g} / \mathrm{m}^{3}$ & 5.6 & 9.44 & 0.17 & 40 \\
\hline $\mathrm{Na}^{+}(\mathrm{IC}) / \mu \mathrm{g} / \mathrm{m}^{3}$ & 4.5 & 11.7 & 0.25 & 37 \\
\hline MSA $/ \mathrm{ng} / \mathrm{m}^{3}$ & 103 & 362 & 1.94 & 44 \\
\hline MSA/nssS & 0.2 & 1.05 & 0.01 & 35 \\
\hline $\mathrm{NH}_{4}+/ \mu \mathrm{g} / \mathrm{m}^{3}$ & 0.3 & 0.97 & 0.01 & 35 \\
\hline $\mathrm{K}^{+} / \mu \mathrm{g} / \mathrm{m}^{3}$ & 0.34 & 5.55 & 0.01 & 42 \\
\hline $\mathrm{Mg}^{2+} / \mathrm{ug} / \mathrm{m}^{3}$ & 0.79 & 4.86 & $<0.01$ & 43 \\
\hline $\mathrm{Ca}^{2+} / \mu \mathrm{g} / \mathrm{m}^{3}$ & 0.27 & 1.6 & 0.01 & 40 \\
\hline $\mathrm{SO}_{2} / \mathrm{ng} / \mathrm{m}^{3}$ & 738 & 1593 & 432 & 30 \\
\hline
\end{tabular}

been made during the summer months). An increase in $\mathrm{CN}$ counts and $\mathrm{SO}_{2}$ concentrations on approaching the coast of Brazil indicated some continental interference. This is corroborated by air mass back trajectories for this period of the cruise (not shown here).

The mean concentration of nssS measured south of the Falkland Islands was $0.78 \mu \mathrm{g} \mathrm{m}^{-3}$ (range $<0.08-3.4 \mu \mathrm{g} \mathrm{m}^{-3}$ ), similar to those reviewed by Fitzgerald [1991] for four studies in the Pacific and Indian Oceans. It is also consistent with the model estimate of Luria et al., [1989] which suggested that DMS oxidation could give rise to about $1 \mu \mathrm{g} \mathrm{m}^{-3}$ sulfate.

The ratio of MSA to nssS, shown in Figure 5, was very low $(0.03)$ in areas north of $58^{\circ} \mathrm{S}$, but with enhanced ratios, with a mean of 0.2 , observed farther south. A maximum for this ratio of 0.7 was seen on the west side of the Antarctic Peninsula, which is in close agreement to the value of 0.6 seen by Berresheim [1987] in the same area. Extremely wide ranges for this ratio have beeñ pireviously observed (e.g., < $0.01-0.9$ in the NE Pacific [Quinn et al., 1993], but this bulk aerosol-

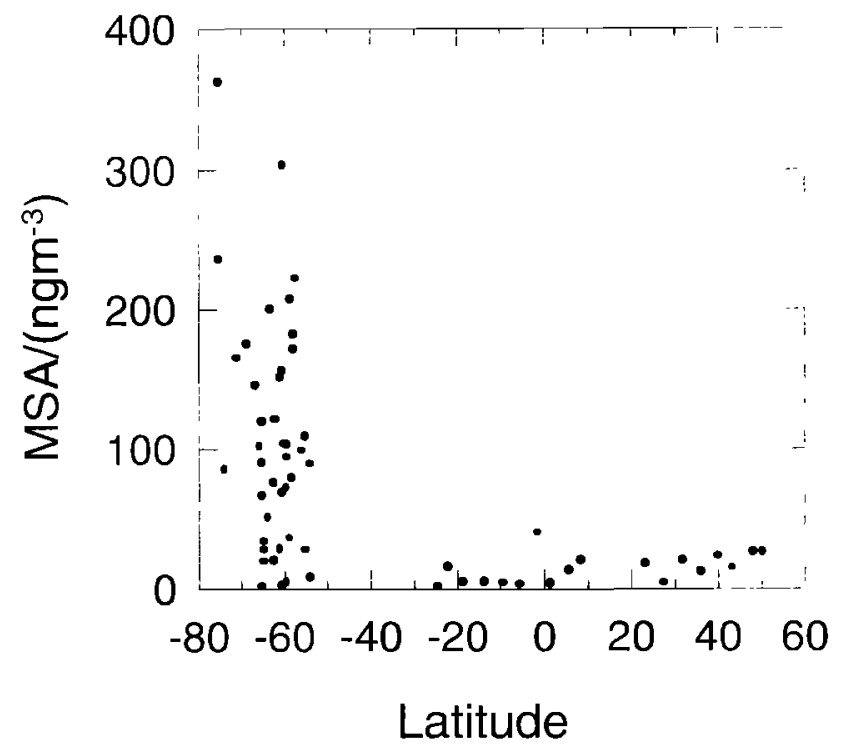

Figure 3. Concentrations of methane sulfonic acid in air with latitude during the cruise of the RRS Bransfield October 2, 1992, to January 10, 1993. derived parameter may, in fact, obscure more useful size dependent information which was not obtainable with the methods used here.

Sulfur dioxide concentrations, shown in Figure 6, were rather variable, with a mean of $0.8 \mu \mathrm{g} \mathrm{m}^{-3}$ (range $0.1-1.6 \mu \mathrm{g}$ $\mathrm{m}^{-3}$ ). These were higher than those of Putaud et al. [1993], measured in the tropical northeastern Atlantic Ocean (mean 0.1 $\mu \mathrm{g} \mathrm{m}^{-3}$ ), and of R. M. Harrison et al. (personal communication, 1996), measured near the Azores $\left(0.1-0.5 \mu \mathrm{g} \mathrm{m}^{-3}\right)$. Luria et al. [1989] found $\mathrm{SO}_{2}$ concentrations near Bermuda to be less than the detection limit of the method used $\left(0.3 \mu \mathrm{g} \mathrm{m}^{-3}\right)$ but predicted higher concentrations of $0.8 \mu \mathrm{g} \mathrm{m}^{-3}$ from DMS oxidation. South of the Falkland Islands the highest concentrations were observed around the Antarctic Convergence Zone (ACZ) and in open water in the Weddell Sea. Considerable uncertainty still surrounds the concentrations and sources of $\mathrm{SO}_{2}$ in the maritime atmosphere. Whether or not the relatively high conicentitratiouns measured in this study are due to unidentıf ted analytical problems, long-range transport of $\mathrm{SO}_{2}$ from continental areas or from DMS oxidation is not clear.

\section{Other Ionic Aerosol Constituents}

$\mathrm{Na}^{+}$concentrations ranged from 0.25 to $15 \mu \mathrm{g} \mathrm{m}^{-3}$ with a mean of $5.5 \mu \mathrm{g} \mathrm{m}^{-3}$ (analyses carried out by both flame photometry and ion chromatography gave similar mean values). This is about twice the mean value reported by Putaud et al. [1993], consistent with the high wind speeds, and hence high concentrations of sea spray, experienced during the cruise. Some enrichment in $\mathrm{Mg}^{2+}$ and, particularly, $\mathrm{Ca}^{2+}$ and $\mathrm{K}^{+}$ concentrations in the aerosol, relative to their seawater concentrations and to the seawater/aerosol ratio for $\mathrm{Na}^{+}$, was observed. The mean and range of these species are shown in Tables 1-3 for the various legs of the cruise.

\section{Aerosol Concentrations and Physicochemical Characteristics}

Variable condensation nuclei (CN) concentrations were observed during the cruise, with the majority less than 1000 $\mathrm{cm}^{-3}$ but with extremes approaching $5000 \mathrm{~cm}^{-3}$. The mean value of $680 \mathrm{~cm}^{-3}$ is above that found by Bates et al. [1987] at $41^{\circ}$ $14^{\circ} \mathrm{S}$ in the Pacific Ocean $\left(380 \mathrm{~cm}^{-3}\right)$ but is similar to that of 


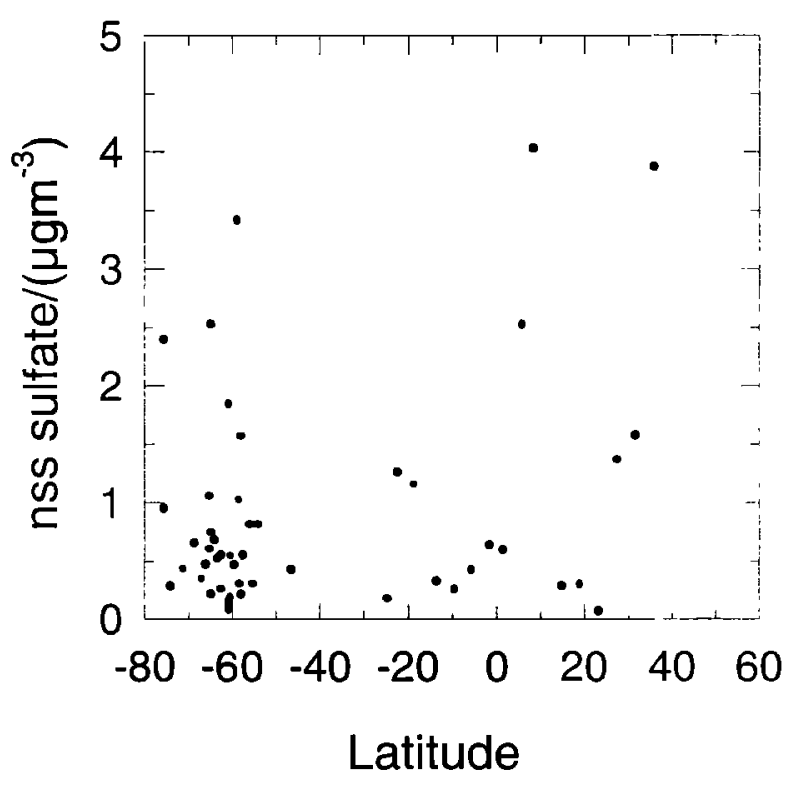

Figure 4. Concentrations of non-sea-salt sulfate in air with latitude during the cruise of the RRS Bransfield October 2, 1992, to January 10, 1993.

Putaud et al. [1993] in the tropical northeastern Atlantic (586 $\mathrm{cm}^{-3}$ ) and to that of R. M. Harrison (personal communication, 1996) in the vicinity of Azores (typically $500 \mathrm{~cm}^{-3}$ ). During the first 10 days of the cruise, from Grimsby to Cape Verde, $\mathrm{CN}$ concentrations were typically $500 \mathrm{~cm}^{-3}$ but fell to $200-300$ $\mathrm{cm}^{-3}$ as the Atlantic was traversed. A rapid increase was seen as South America was approached, indicating detection of long. range transported pollutant aerosol. On the passage from Montevideo to Port Stanley, high concentrations of CN (up to $4000 \mathrm{~cm}^{-3}$ ) were again observed.

During the Antarctic legs of the cruise the total particle background concentration was around $400-600 \mathrm{~cm}^{-3}$ with frequent periods when the concentration peaked at values in excess of $4000 \mathrm{~cm}^{-3}$. These peaks are attributed to bursts of new particle formation and are discussed in the following section. A background $\mathrm{CN}$ level of around $600 \mathrm{~cm}^{-3}$ is in good agreement with observations at similar latitudes in other regions over the Antarctic for the same time of year [Gras, 1993a; Ito, 1993].

Table 4 displays the means and extremes of the total particle concentration and accumulation mode $(0.05 \mu \mathrm{m}\langle r\rangle$ $0.2 \mu \mathrm{m}$ ) partitioning observed for all data during periods that both the $C N$ and the ASASP-X particle counters were operational simultaneously. For the Antarctic legs only (south of $58^{\circ} \mathrm{S}$ ), the average $\mathrm{CN}$ concentration observed was $910 \mathrm{~cm}^{-3}$, with a minimum value of $150 \mathrm{~cm}^{-3}$ and a maximum of 4325 $\mathrm{cm}^{-3}$. In comparison, the accumulation mode average concentration was $25 \mathrm{~cm}^{-3}$ with maximum and minimum values of $65 \mathrm{~cm}^{-3}$ and $4 \mathrm{~cm}^{-3}$, respectively, agreeing well with the accumulation mode average of $27 \mathrm{~cm}^{-3}$ observed by Harvey et al. [1991] but very much less than previously seen over the North Atlantic where anthropogenic influences are more common [e.g., O'Dowd et al., 1993].

The accumulation mode aerosol can be broken into two components, nss sulfate and sea salt, determined using the volatility technique [Jennings and $O^{\prime}$ Dowd, 1990; O'Dowd and Smith, 1993], and these are tabulated in Table 5. The average percentage number concentration of sea salt in the accumulation mode was observed to be $18 \%$ with a minimum of

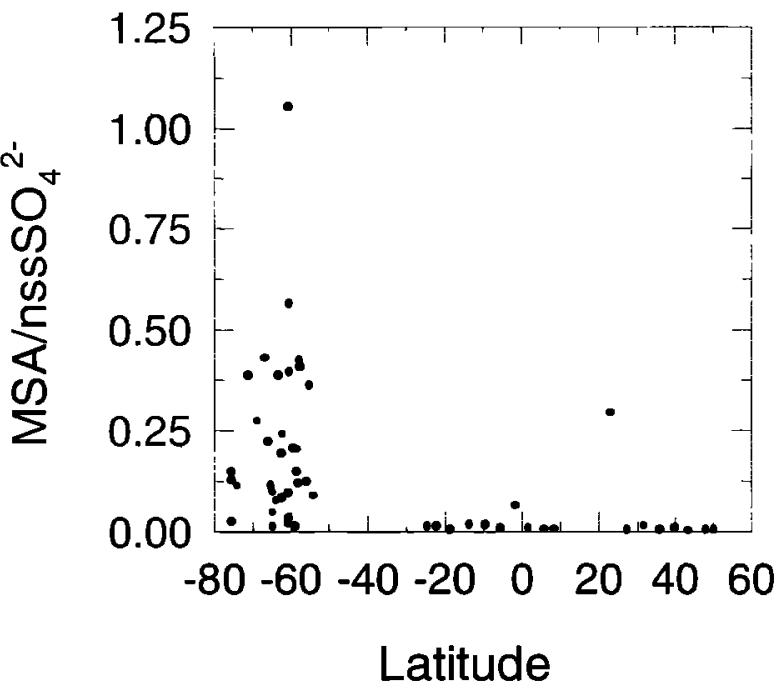

Figure 5. Ratio of methane sulfonic acid to non-sea-salt sulfate as a function of latitude during the cruise of the RRS Bransfield October 2 , 1992, to January 10, 1993.

$2 \%$ and a maximum of $97 \%$. The actual fraction of accumulation mode aerosol to the total aerosol concentration was very much less than anticipated, with the accumulation mode aerosol comprising, on average, $4 \%$ of the total $\mathrm{CN}$ concentration with a maximum contribution of $14 \%$. This low fraction is quite surprising since previously reported fractions are as high as 50\% [Jennings et al., 1991; Fitzgerald, 1991, and references therein]. The reason for the lower fraction of accumulation mode aerosol to total aerosol concentrations may be due to an enhanced new particle production rate resulting from the combined effect of the low surface area sink associated with existing aerosol in this very clean environment, with both low temperatures and extended periods of solar irradiation in the region which would favor homogeneous nucleation [Seinfeld, 1986; Wayne, 1991].

Particles within the accumulation mode size range and larger are of particular importance in direct and indirect climate forcing processes and therefore warrant more detailed

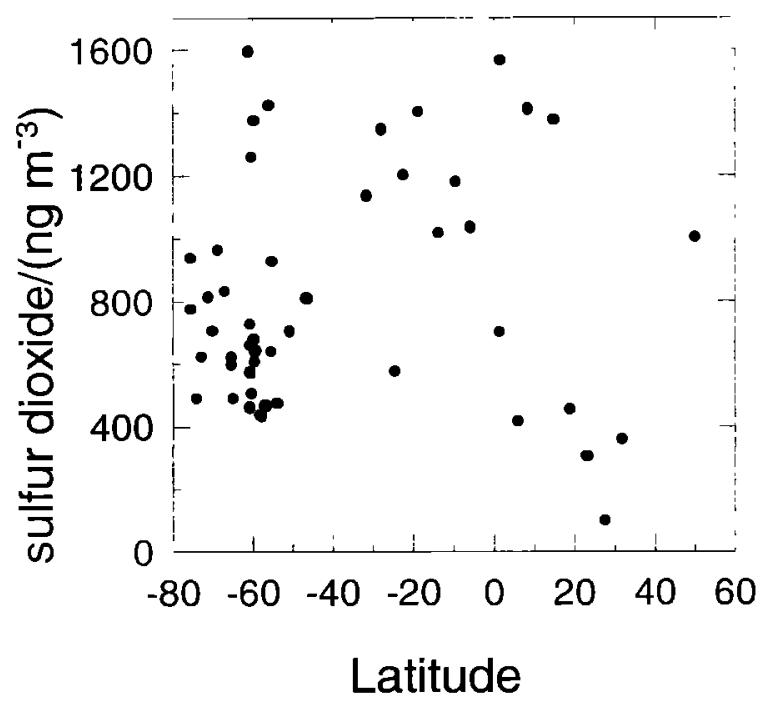

Figure 6. Concentrations of sulfur dioxide in air with latitude during the cruise of the RRS Bransfield October 2, 1992, to January 10, 1993. 
Table 4. Summary of Condensation Nuclei and Accumulation Mode Number Densities for Measurements Made South of $58^{\circ} \mathrm{S}$

\begin{tabular}{|c|c|c|c|c|}
\hline & $\mathrm{CN} / \mathrm{cm}^{\mathrm{J}}$ & $\mathrm{CN} / \mathrm{cm}^{3}$ & $\begin{array}{l}\text { Percent Volatile } \\
\text { Fraction }\end{array}$ & $\begin{array}{l}\text { Accumulation } \\
\text { Mode/CN, \% }\end{array}$ \\
\hline Mean & 910 & 25 & 18 & 4 \\
\hline s.d. & 766 & 12 & 17 & 2.5 \\
\hline Minimum & 150 & 4 & 2 & 0.3 \\
\hline Maximum & 4325 & 65 & 97 & 14 \\
\hline
\end{tabular}

breakdown, as shown in Table 5. As previously mentioned, externally mixed sea salt and nss sulfate aerosol within the accumulation mode were discerned and the relative contribution of the two aerosol species to number concentration, surface area, and volume determined. From Table 5 it may be seen that the number concentration is generally dominated, over the whole period, by the nss sulfate aerosol with an average value of $21 \mathrm{~cm}^{-3} \mathrm{nss}$ sulfate particles and $4 \mathrm{~cm}^{-3}$ sea salt particles. It is interesting to note that the maximum number of salt particles observed $\left(61 \mathrm{~cm}^{-3}\right)$ was similar to the maximum number of nss sulfate particles observed $\left(64 \mathrm{~cm}^{-3}\right)$. There were periods when the ASASP-X was not operational due to laser failure which, unfortunately, coincided with the period of highest wind speeds, and therefore the contribution of sea salt to the accumulation mode concentration, and the peak sea salt concentration, is likely to be underestimated. In terms of surface area the two aerosol species make a similar contribution (within the accumulation mode) with values of $1.5 \mu \mathrm{m}^{2} \mathrm{~cm}^{-3}$ and $1.6 \mu \mathrm{m}^{2} \mathrm{~cm}^{-3}$ for sea salt and nss sulfate, respectively. Accumulation mode volume is primarily dominated by the sea salt aerosol, with a mean value of $0.15 \mu^{3} \mathrm{~cm}^{-3}$ compared with $0.04 \mu \mathrm{m}^{3} \mathrm{~cm}^{-3}$ for nss sulfate. It should be noted that the data presented here are for a dry aerosol, thus actual surface area and volume are likely to be significantly higher, varying with ambient relative humidity. These data are not representative of open ocean aerosol characteristics since much of the data were observed over broken pack ice regions where sea surface exposure, and consequently sea-to-air transfer of primary aerosols and precursor gases, is very much reduced.

Aerosol size distribution characteristics were found to be strongly related to air mass origin. There were typically two air masses observed during the Antarctic legs of the cruise, a "pure" maritime air mass which was associated with the tracking of cyclonic weather systems at latitudes of around $50^{\circ}$. $60^{\circ} \mathrm{S}$ and a polar air mass advecting out from the continent over the pack ice region, associated with the diverging outflow

Table 5. Summary Accumulation Mode Characteristics South of $58^{\circ} \mathrm{S}$

\begin{tabular}{|c|c|c|c|c|c|c|c|c|c|}
\hline & \multicolumn{3}{|c|}{$\begin{array}{l}\text { All } \\
\text { Particles }\end{array}$} & \multicolumn{3}{|c|}{$\begin{array}{l}\text { nss- } \\
\text { Sulfate } \\
\text { Particles }\end{array}$} & \multicolumn{3}{|c|}{$\begin{array}{l}\text { Sea-Salt } \\
\text { Particles }\end{array}$} \\
\hline & $\begin{array}{c}\mathrm{N} \\
\mathrm{cm}^{3}\end{array}$ & $\begin{array}{r}\mathrm{SA} \\
2 \\
\mu \mathrm{m}^{2} \\
\mathrm{~cm}^{3}\end{array}$ & $\begin{array}{c}\mathrm{V} \\
\mathrm{\mu m}^{3} \\
\mathrm{~cm}^{3}\end{array}$ & $\begin{array}{c}\mathrm{N} \\
\mathrm{cm}^{3}\end{array}$ & $\begin{array}{c}\mathrm{SA} \\
\mu^{2} \\
\mathrm{~cm}^{3}\end{array}$ & $\begin{array}{c}\mathrm{V} \\
\mu \mathrm{m}^{3} \\
\mathrm{~cm}^{3}\end{array}$ & $\begin{array}{c}\mathrm{N} \\
\mathrm{cm}^{3}\end{array}$ & $\begin{array}{c}\mathrm{SA} \\
\mu \mathrm{m}^{2} \\
\mathrm{~cm}^{3}\end{array}$ & $\mu_{\mathrm{m}^{-3}}^{\mathrm{V}}$ \\
\hline Mean & 25.34 & 3.17 & 0.194 & 20.88 & 1.654 & 0.043 & 4.46 & 1.151 & 0.151 \\
\hline Standard & 12.62 & 1.83 & 0.157 & 12.56 & 1.440 & 0.088 & 5.14 & 1.738 & 0.173 \\
\hline Error & 0.6 & 0.09 & 0.007 & 0.597 & 0.068 & 0.004 & 0.244 & 0.082 & 0.008 \\
\hline Minimum & 3.36 & 0.583 & 0.024 & 0.28 & $-9^{*}$ & $-0.8 *$ & 0.28 & 0.043 & 0.002 \\
\hline Maxium & 71.46 & 11.06 & 0.959 & 63.98 & 7.793 & 0.537 & 61.18 & 14.48 & 1.318 \\
\hline
\end{tabular}

All accumulation mode data south of $58^{\circ} S . N, S A$, and $V$ are accumulation mode number concentration, surface area, and volume, respectively.

- Negative values result from partial volatilization of particles larger than the ASASP-X measurement range (which can, at times, dominate volume and surface area) and the propagation of these particles into the measurement range. 


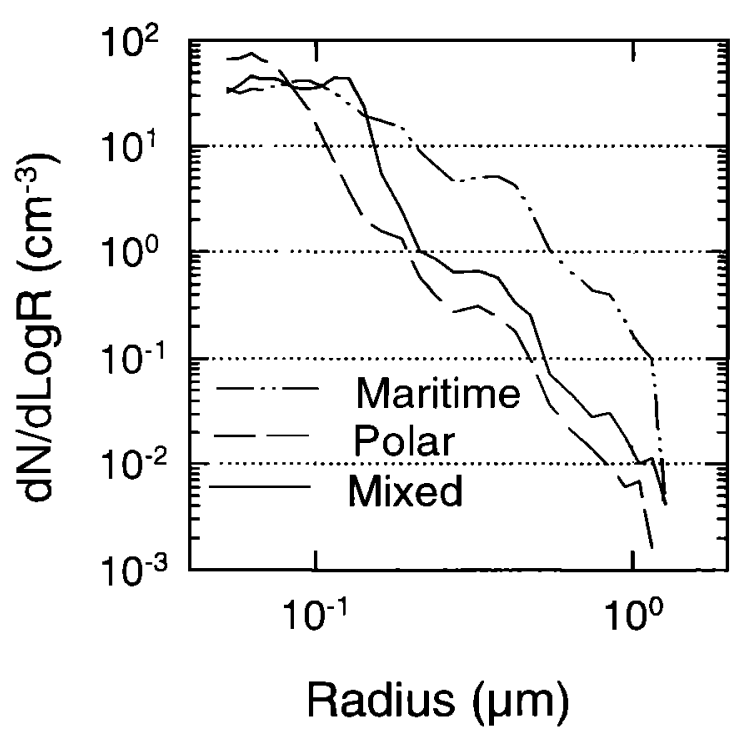

Figure 7. Typical accumulation mode size distributions assocjated with polar, maritime, and mixed polar and maritime air masses.

due to the prevailing polar high-pressure system. Aerosol associated with these two air mass types possessed distinct spectral and chemical characteristics. A third aerosol type resulted from the mixing of these two air masses, along with subsequent passage over the upwelling region around the Antarctic convergence zone. Figure 7 shows typical accumulation mode aerosol spectra for the maritime, polar, and mixed air masses with the corresponding polar and marine air mass back trajectories displayed in Figure 8. The spectra for maritime air exhibit a higher mode radius $\left(r_{m}=0.09 \mu \mathrm{m}\right)$, which shows good agreement with North Atlantic aerosol [O'Dowd et al., 1993], compared with the polar spectrum $\left(r_{m}=0.06 \mu \mathrm{m}\right)$.

A double-peaked distribution was observed for the mixed aerosol type occurring around the Antarctic convergence zone. This size distribution is thought to result from polar aerosol extending over the upwelling region where gaseous precursor emissions are high, leading to enhanced heterogeneous gas-toparticle conversion. The mode radius $\left(r_{m}=0.13 \mu \mathrm{m}\right)$ of the righthand peak is much higher than that normally observed and may be attributed to extensive cloud processing [Hoppel et al., 1986; 1994]. The smaller mode radius associated with polar aerosol compared with marine aerosol is thought to be due to less cloud cover, and consequently less cloud processing, over the continent and pack ice regions and is in good agreement with other observations at these latitudes [Harvey et al., 1990; Ito, 1993; Gras, 1993b]. For all spectra observed, particles larger than $0.15 \mu \mathrm{m}$ radius were composed of sea salt, with the difference in the size distributions at these sizes being due to wind speed related sea salt aerosol generation. In the size range $0.05-0.15 \mu \mathrm{m}$ radius, sea salt was also present, but the relative amount depended on the varying source strengths of both nss sulfate and sea salt.

More detailed volatility analysis of these samples also revealed further differences in the two aerosol types, particularly in the nature of the nss sulfate. This aspect of the data is fully discussed by C. D. O'Dowd et al., Biogenic sulfur emissions and inferred nss-sulfate $\mathrm{CCN}$ in and around Antartica, submitted to Journal of Geophysical Research, 1996. The marine nss sulfate aerosol was generally neutralized by ammonia leading to ammonium sulfate/bisulfate, with
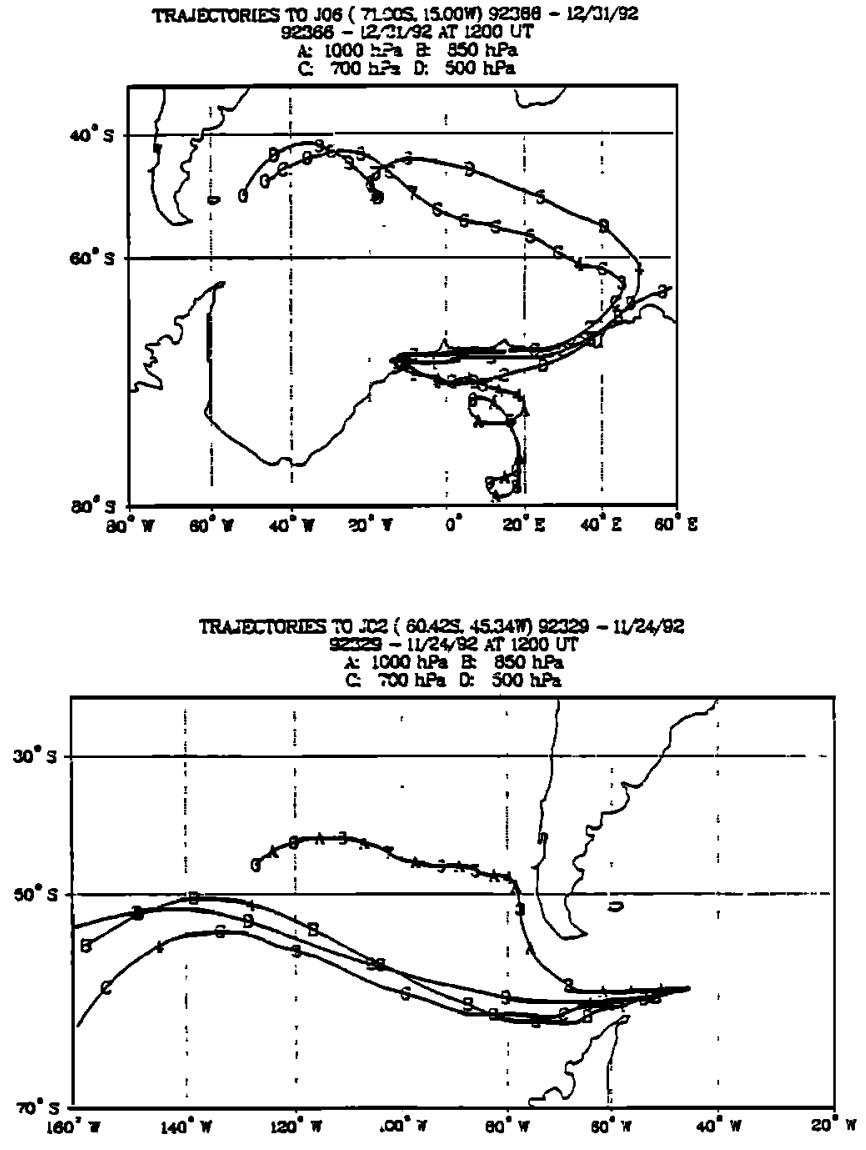

Figure 8. Air mass back trajectories associated with polar and marine air masses.

$\mathrm{NH}_{4}{ }^{+} / \mathrm{SO}_{4}{ }^{2-}$ molar ratios near 1 (the volatility technique cannot detect molar ratios higher than 1). In comparison, polar air nss sulfate was present primarily in the form of $\mathrm{H}_{2} \mathrm{SO}_{4}$, with molar ratios near zero, suggesting a deficit of ammonia in the polar air masses and resulting in a strong latitudinal molar ratio gradient.

\section{New Particle Formation}

During the cruise, many periods of both sudden and gradual enhancement of the $\mathrm{CN}$ concentration were observed and are attributed to new particle nucleation in the 'clean' marine environment, as opposed to pollution events. Most of these cases were observed over the Weddell Sea in the broken pack ice region rather than over the open ocean. These cases can be illustrated by using the combined epiphaniometer surface area data, accumulation mode surface area, and concentration data and $\mathrm{CN}$ concentrations.

Epiphaniometer counts measured aboard the RRS Bransfield showed a very variable signal with observed minima around 9000 counts $/ 30$ min sampling period and maxima of about 50,000 . It is not possible to directly compare these data with previous epiphaniometer measurements because this was the first time that the instrument has been used during an ocean cruise. However, the data obtained were similar to those seen at the elevated European Alpine sites of Colle Gnifetti (4450 m (asl)) and Jungfraujoch (altitude 3450 metres asl) where signals of $<10,000$ counts/30 min are thought to represent clean free 


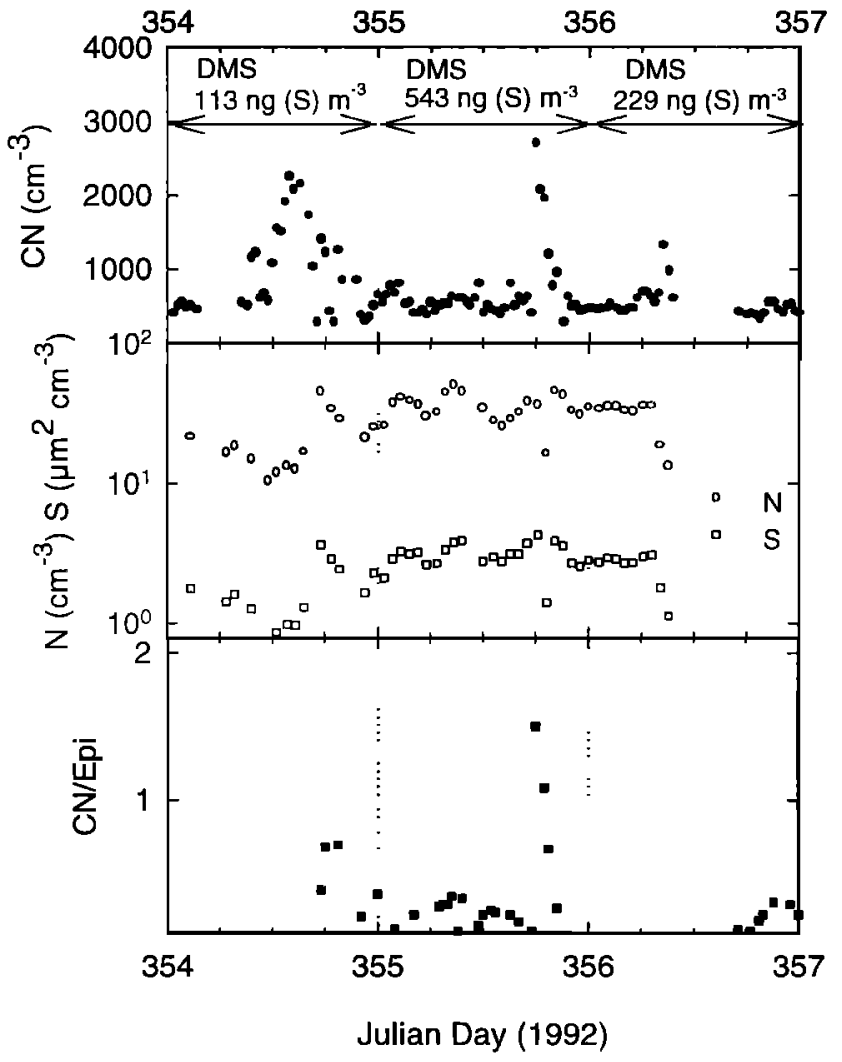

Figure 9. (Top) Condensation nuclei (CN) concentrations for three cases of new particle formation from (Julian Day) 354 to JD 357. (Middle) Accumulation mode aerosol concentration and surface area for JD 354 to JD 357. (Bottom) CN/epiphaniometer ratio for JD 354 to JD 35.

tropospheric air, and peaks up to about 70,000 counts $/ 30 \mathrm{~min}$ occur during pollution events [Baltensperger et al., 1991]. Because the epiphaniometer signal is not linearly proportional to the geometric surface area or volume of the sampled aerosol (D $<100 \mathrm{~nm}$, signal $\alpha \mathrm{D}^{2} ; 100 \mathrm{~nm}<\mathrm{D}<3 \mu \mathrm{m}$, signal $\alpha \mathrm{D}^{\mathrm{x}}$ with $X$ varying between 1 and 2 , depending on $D ; D>3 \mu \mathrm{m}$, signal $\alpha$ D) [Pandis et al., 1991], it is not possible to calculate the geometric surface area of the aerosol from the signal unless the size distribution is known. However, for a background aerosol of constant size distribution it has been shown that 1000 counts $/ 30 \mathrm{~min}$ correspond roughly to an aerosol mass concentration of $0.5 \mathrm{\mu g} \mathrm{m}^{-3}$ [Baltensperger et al., 1991].

The epiphaniometer signal is based on a diffusional process (the diffusion of lead atoms to the surface of the existing aerosol particles). Thus this signal represents the surface area a diffusing molecule sees of these aerosol particles. A useful parameter to consider in the context of new particle formation is therefore the ratio of particle number concentration to epiphaniometer signal. Changes in this ratio suggest a change in the size distribution of the aerosol: a high ratio suggests the presence of increased numbers of small particles which have a low Fuchs surface area, indicating a possible nucleation burst, while a lower ratio suggests that a combination of coagulation processes, condensational growth, and heterogeneous reactions have occurred in the absence of significant new, small-particle formation. An alternative method to identify events of CN nucleation, as opposed to pollution events, is to examine the accumulation mode aerosol in conjunction with the $\mathrm{CN}$ concentrations. Pollution, or contamination, events will lead to high concentrations of $\mathrm{CN}$ but also lead to accumulation mode concentrations and surface area being elevated well above the clean background levels observed during the cruise, thereby rendering these events easily identifiable.

By way of illustration, three examples of new particle formation, from Julian day (JD) 354 to JD 357 are shown in Figure 9. Over this 3-day period the ship was moving from $68^{\circ} \mathrm{S}$ to $73^{\circ} \mathrm{S}$ through a region of thick, melting, pack ice where DMS fluxes are likely to be elevated [Kirst et al., 1992]. DMS concentrations were quite high, with values of 113,543 , and $382 \mathrm{ng}(\mathrm{S}) \mathrm{m}^{-3}$ on Julian days 354,355 , and 356 , respectively. During JD 354, CN concentrations were reasonably constant at about $600 \mathrm{~cm}^{-3}$ until JD 354.5 when they rapidly increased to nearly $3000 \mathrm{~cm}^{-3}$. If this increase was due to pollution, then a similar increase would have been observed in the accumulation mode aerosol. In fact, an opposite trend is observed in accumulation mode concentration and surface area, suggesting that $\mathrm{CN}$ the concentration increase resulted from new particle formation. Epiphaniometer data were not available during this period.

A very interesting case of new particle formation was also observed on the following day, JD 355, when there was a sudden decrease in accumulation mode number concentration and surface area, possibly due to precipitation, followed by a sudden and sharp increase in $\mathrm{CN}$ concentration. Hoppel and Frick [1990] also observed such a nucleation event after precipitation scavenging over the South Pacific. Shortly after, the $\mathrm{CN}$ concentration reduced steadily to the background level. The reduction in accumulation mode surface area and increase in CN concentration are also illustrated by the CN/epiphaniometer ratio, consistent with new particle formation.

The final case presented in this sequence also exhibits a reduction in accumulation mode concentration and surface area with an associated, albeit modest, increase in $\mathrm{CN}$ concentration. Again, there are no reliable epiphaniometer data for this period. From these examples it seems likely that the surface area of the preexisting aerosol plays an important role in inducing bursts of new particle formation by adjusting the relative importance of competing binary homogeneous nucleation of sulfuric acid - water vapor and condensational growth processes. At high surface areas the existing aerosol can provide a good sink for gas phase precursors, while at low surface area and the same precursor vapor source strength, the build up of precursor vapor is more likely to reach a greater supersaturation level where homogeneous nucleation of new particles is favored [Seinfeld, 1986].

For the cases presented here, it appears that homogeneous nucleation is favored over condensation under conditions when the aerosol surface area falls below a value of between 1 and 1.5 $\mu \mathrm{m}^{2} \mathrm{~cm}^{-3}$ (4-6 $\mu^{2} \mathrm{~cm}^{-3}$ when corrected to ambient humidity, $75-80 \%$ ), which compares favorably with the threshold of 5 $\mu \mathrm{m}^{2} \mathrm{~cm}^{-3}$ (dry) reported by Covert et al. [1992] and $6 \mu \mathrm{m}^{2} \mathrm{~cm}^{-3}$ (wet) reported by Gras [1993b]. It seems likely that there is a linkage between new particle formation and aerosol surface area, as illustrated in Figure 10, where enhanced $C N$ concentrations are observed for dry surface areas less than 1.5 $\mu \mathrm{m}^{2} \mathrm{~cm}^{-3}$. Although there are some elevated $\mathrm{CN}$ concentrations at surface areas larger than $1.5 \mu^{2} \mathrm{~cm}^{-3}$ (shown in open circles), these high concentrations only occur after nucleation bursts when the aerosol surface area has increased over a timescale shorter than that required for coagulation and dilution 


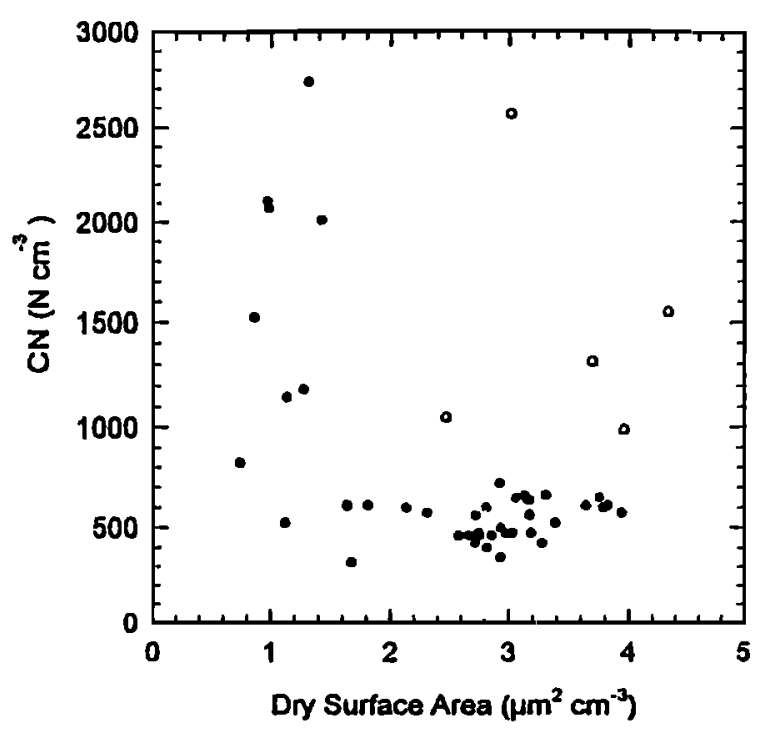

Figure 10. Scatterplot of $\mathrm{CN}$ concentration versus dry surface area for all data from JD 354 to JD 357.

losses to reduce the $\mathrm{CN}$ concentration. The surface area presented here from the ASASP-X is not a measure of total surface area of the aerosol since there will be contributions from the sea salt aerosol extending to sizes well in excess of 1 $\mu \mathrm{m}$ [Smith et al., 1989] along with the fine particle mode at sizes smaller than $0.05 \mu \mathrm{m}$. However, because of the minimal sea salt input resulting from polar air advecting over broken pack ice, where salt production is very much less than that over open water, combined with examination of the surface area distributions of Ito [1993], we may assume that the ASASP-X surface area is close to the total dry surface area.

These data are consistent with theoretical predictions of new particle nucleation for quasi-static environmental conditions. Modeling studies predict that the existing aerosol surface area, if below a certain threshold value for a given temperature, relative humidity, and precursor vapor source strength, cannot provide a sufficient condensation sink for the gas phase vapor and thus allows the vapor precursor to accumulate and achieve its required critical vapor supersaturation to initiate homogeneous nucleation [Lin et al., 1992; Raes and Van Dingenen, 1992]. The threshold surface area values reported here must only be considered as characteristic for these particular nucleation events and the environmental conditions associated with these cases. They are not meant to be applied to other environments or conditions and should only be viewed as illustrative of the potential effect of aerosol surface area on homogeneous nucleation of new particles. In view of the lack of more detailed surface area distributions and aerosol precursor gas phase measurements, they must also be taken as approximate representations of these events.

When the nucleation burst on JD 355 is examined using the maximum temporal resolution available in the data set $15-\mathrm{min}$ averages), a peak CN concentration of $3500 \mathrm{~cm}^{-3}$ was observed, compared with a previous background level of $550 \mathrm{~cm}^{-3}$. From this $\mathrm{CN}$ increase over a 15 -min timescale the minimum new particle formation rate may be estimated to be $3.2 \mathrm{~cm}^{-3} \mathrm{~s}^{-1}$. During sampling in this environment the observed ambient temperature of $-3^{\circ} \mathrm{C}$ and relative humidity of $75 \%$ would strongly affect the nucleation process, which is promoted by lower temperatures and higher humidities [Jaecker-Voirol and Mirabel, 1989]. By linear interpolation of the graphs presented by Jaecker-Voirol and Mirabel [1989], a sulfuric acid molecular vapor concentration of $5 \times 10^{7}( \pm 20 \%) \mathrm{cm}^{-3}$ is required to produce this nucleation rate. This sulfuric acid vapor concentration is not unlikely considering the small sink provided by the relative humidity-corrected surface area of 4.5 $\mu \mathrm{m}^{2} \mathrm{~cm}^{-3}$, the relatively high DMS concentration (543 $\mathrm{ng}(\mathrm{S})$ $\mathrm{m}^{-3}$ ), and 24-hour sunlight enhancing the sulfuric acid production mechanism by its effects on the production of the $\mathrm{OH}$ radical (a major ingredient in the homogeneous sulfuric acid production process). This nucleation burst is very similar to the case reported by Covert et al. [1992], although over a much shorter timescale, hence giving a nucleation rate about 3 times larger than that of Covert et al. [1992]. Although they concluded that their nucleation rate was far too high, the nucleation rate calculated on JD 355 (and the required sulfuric acid vapor concentration), may not be unreasonable for the very different Antarctic conditions, with considerably lower temperatures and 24-hour sunlight.

While the observed increase of boundary layer $\mathrm{CN}$ concentrations are attributed to new particle formation in the boundary layer, we must examine the likelihood of the high $\mathrm{CN}$ concentrations resulting from tropospheric entrainment. Assuming an entrainment rate of $0.34 \mathrm{~cm} \mathrm{~s}^{-1}$ [Berresheim et al., 1990 , and references therein] and taking the actual boundary layer height of $680 \mathrm{~m}$, an unlikely free tropospheric $\mathrm{CN}$ concentration of greater than $6 \times 10^{5} \mathrm{~cm}^{-3}$ is required to account for the observed boundary layer concentrations. The required free tropospheric $\mathrm{CN}$ concentration is considerably higher than the peak concentrations observed by Clarke [1992], thus suggesting that the enhanced $\mathrm{CN}$ concentrations result from boundary layer nucleation bursts rather than tropospheric entrainment.

After the nucleation burst on JD 355 the $\mathrm{CN}$ concentration decays rapidly over a couple of hours, suggesting a rapid loss mechanism. This rapid decay is likely to be due to a combination of three possible processes: (1) horizontal dispersion and/or advection; (2) vertical mixing; and (3) coagulation. To examine the contribution of horizontal mixing to the CN decay, we can use a highly simplified turbulent dispersion model of an expanding cylindric column with uniform concentration of particles throughout the column and conserving particle numbers within the column, leading to an analytical time dependent description of concentration in the form of $n=\left(n_{0} a^{2}\right) /(a+s)^{2}$, where the horizontal dispersion $s=$ $(2 D t)^{0.5}$ [Boeker and van Grodelle, 1995], $D$ is the eddy diffusivity, $t$ is time, $n$ is the concentration of $C N$ with initial value $n_{0}, a$ is the radius of the region over which the nucleation event occurs, and $s$ is the surface area.

If horizontal mixing was the primary dilution effect, then it must be able to explain elevated $\mathrm{CN}$ concentration three hours after the nucleation event. Taking the observed wind speed of 5 $\mathrm{m} \mathrm{s}^{-1}$, a temporal timescale of 3 hours corresponds to a horizontal dispersion of more than $50 \mathrm{~km}$. Using the dispersion equation however, the maximum value of the horizontal dispersion is less than $1 \mathrm{~km}$, even if a large value of $D=10 \mathrm{~m}^{2} \mathrm{~s}^{-1}$ [Stull, 1988] is assumed. This modest value suggests a negligible effect of horizontal dispersion on $\mathrm{CN}$ concentrations over the timescale of a few hours and, when combined with the observed elevated $\mathrm{CN}$ concentrations three hours later, suggests that the nucleation event took place over spatial scales of greater than $10 \mathrm{~km}$.

If the rapid decay had resulted from advection, then the 
measurement point must be on the periphery of the burst region. The decline in $\mathrm{CN}$ must then result from a move out of the burst region into a region into which the new particles have not yet mixed. We have estimated the horizontal dispersion to be less than $1 \mathrm{~km}$, and taking the observed wind speed of $5 \mathrm{~m} \mathrm{~s}$ 1 , it follows that the time taken to traverse this transition region (from the elevated $\mathrm{CN}$ region to the background $\mathrm{CN}$ region) is, at most, $200 \mathrm{~s}$. The short timescale is not consistent with the observations of $\mathrm{CN}$ decline over more than 3 hours and thus suggests that advection cannot account for the decline in the $\mathrm{CN}$ concentrations.

The rate of change of $\mathrm{CN}$ concentration with time resulting from combined vertical mixing and coagulation may be estimated by

$$
d n / d t=-\left(k n / 2+\left\{v_{d} / H\right\}\right) n
$$

where $n$ is the total concentration of $\mathrm{CN}, \boldsymbol{k}$ is the coagulation kernel, $v_{d}$ is the entrainment velocity, and $H$ is the boundary layer mixing height.

This differential equation integrates to

$$
n=\left\{a n_{0} /\left\{n_{0}+a\right\} e^{-b t}\right\} /\left\{1-n_{0} /\left\{n_{0}+a\right\} e^{-b t}\right\}
$$

where $b=v_{d^{\prime}} H$ and $a=2 b / k$ and $n_{0}$ is the CN concentration at time $t=0$.

Taking a typical entrainment velocity of $0.34 \mathrm{~cm} \mathrm{~s}^{-1}$ and a boundary layer height of $680 \mathrm{~m}$, this equation is shown to provide an excellent fit to the $\mathrm{CN}$ decay curve in Figure 11, resulting in a coagulation kernel $k=2.11 \times 10^{-7} \mathrm{~cm}^{-3} \mathrm{~s}^{-1}$ (defined as the average coagulation coefficient weighted according to the shape of the distribution of the coagulation particles). From the parameters used in the curve fit we determine the dominating loss mechanism to be coagulation loss, contributing $99 \%$ to particle loss immediately after the nucleation burst and reducing to $89 \%$ three hours later. We should note that when the entrainment rate is increased by an order of magnitude, the value of $k$ is decreased by less than a factor of 2 and results in a much poorer fit to the observed data.

From the equation of the curve, it is calculated that after 3 4 hours the total number of $\mathrm{CN}$ approaches the background concentration. This timescale is less than that required for the new particles to grow to a size at which they may become active as CCN [Raes and Van Dingenen, 1992; Hegg, 1990; Lin et al., 1992], thus suggesting these bursts have a minimal influence on enhancement of the long-term $\mathrm{CN}$ and $\mathrm{CCN}$ concentrations. Without spectral information and detailed modeling analysis, it is not possible to determine whether selfcoagulation in the new particle size range or coagulation involving the larger preexisting aerosol dominates the reduction process. However, comparing the coagulation kernel obtained from this study $\left(2.11 \times 10^{-7} \mathrm{~cm}^{3} \mathrm{~s}^{-1}\right)$ with individual coefficients, for coagulation of particles of $2.5 \mathrm{~nm}$ and $150 \mathrm{~nm}$ wet radii $\left(4.0 \times 10^{-7} \mathrm{~cm}^{3} \mathrm{~s}^{-1}\right)$, for self-coagulation between small particles $\left(1.9 \times 10^{-9} \mathrm{~cm}^{3} \mathrm{~s}^{-1}\right)$, and for self-coagulation between accumulation mode particles $\left(9.6 \times 10^{-10} \mathrm{~cm}^{3} \mathrm{~s}^{-1}\right)$ determined using the formulae of Fuchs at $0^{\circ} \mathrm{C}$ [Seinfeld, 1986]. The large value of the coagulation kernel suggests that the process in which new small particles collide with the larger preexisting aerosol is probably the most important. It is anticipated that toward the end of the decay process, as the $\mathrm{CN}$ concentration approaches the background level, the value of the coagulation

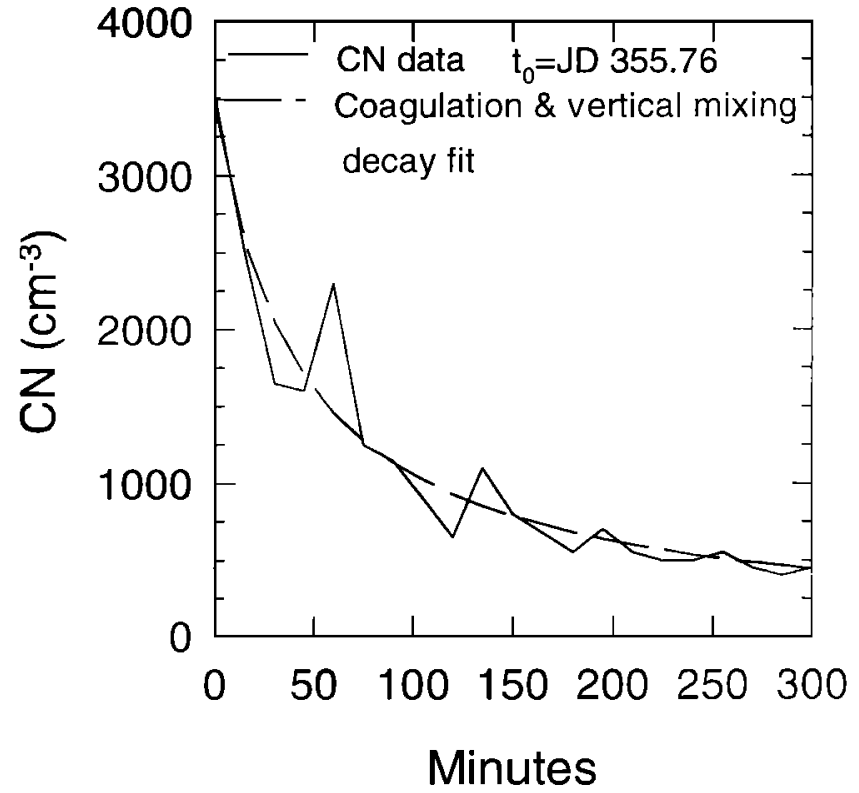

Figure 11. CN data and fitted coagulation decay curve for nucleation burst on JD 355 .

kernel will slowly decrease, reflecting the changes in spectral shape due to the removal of the new particle mode formed from the nucleation burst. While there seems to be no significant enhancement of the $\mathrm{CN}$ and $\mathrm{CCN}$ concentrations from this brief nucleation burst, this should not be confused with the case reported by Covert et al. [1992] where an extended period of nucleation was observed and did result in an increase in $\mathrm{CN}$ concentrations and, possibly, CCN concentrations.

Apart from these cases of obvious new particle formation it appears that there is a constant, albeit much more modest, nucleation rate which maintains the background $C N$ concentration at between $400 \mathrm{~cm}^{-3}$ and $600 \mathrm{~cm}^{-3}$. To make some estimate of the source strength required to sustain this background level, and in the absence of size-resolved information outside the range of the ASASP-X, it is necessary to make some assumptions regarding the form of the spectra. The background spectra are assumed to have a similar form to that observed by Ito [1993] for the month of December. By scaling Ito's coagulation time constant to take account of our different number concentrations, a $k$ value of $8.5 \times 10^{-9} \mathrm{~cm}^{3} \mathrm{~s}^{-1}$ is obtained. The difference between this value and that obtained for the nucleation burst is not unexpected, given the likely difference in spectral forms and number concentration between the two scenarios. If we assume that the source of these new particles is homogeneous nucleation in the boundary layer then, using this $k$ value and placing $22 \%$ of the particles in the new particle mode, a nucleation rate of between $3.0 \times 10^{-4} \mathrm{~cm}^{-3}$ $\mathrm{s}^{-1}$ and $6.8 \times 10^{-4} \mathrm{~cm}^{-3} \mathrm{~s}^{-1}$ (or between 26 and 58 particles $\mathrm{cm}^{-3}$ $\mathrm{d}^{-1}$ ) is estimated to maintain the background concentration. These formation rates are in good agreement with the figures presented by Hoppel [1988] and Ito [1993]. If the background CN concentration is maintained by boundary layer homogeneous nucleation, it is not clear whether it is sustained by a constant nucleation rate or by intermittent but more intense microscale nucleation bursts, which when viewed over the timescales in this data set appear as a constant rate.

Clarke [1992] and Raes [1995] suggested that tropospheric entrainment can also provide a constant source of nuclei and may account for the boundary layer background concentration 
and source strength. Calculations suggest that for tropospheric entrainment of nuclei to be a viable mechanism, it must be able to provide a source of nuclei at a rate of between (3.0 - 6.8) $\mathrm{x}$ $10^{-4} \mathrm{~cm}^{-3} \mathrm{~s}^{-1}$ which, using an entrainment rate of $0.34 \mathrm{~cm} \mathrm{~s}^{-1}$ and a boundary layer height of $680 \mathrm{~m}$, requires free troposphere CN concentration of between 460 and $740 \mathrm{~cm}^{-3}$. Free tropospheric $\mathrm{CN}$ concentrations of this magnitude are common and tend to represent the lower end of the free tropospheric $\mathrm{CN}$ concentration spectrum [Clarke, 1992], thus suggesting this mechanism may explain the source of background nuclei.

Further effort is needed to elucidated whether the background $\mathrm{CN}$ concentration is maintained by constant or moderate and frequent nucleation events or by entrainment from the free troposphere. It should be noted that while these nucleation events are attributed to binary homogeneous nucleation of particles, there may be other processes that form new particles such as heterogeneous nucleation upon cluster ions or on low volatility embryos [Hoppel et al., 1994].

The exact source of the aerosol precursor gases is also not clear: sulfur dioxide from long-lived precursor gases such as $\mathrm{CS}_{2}$ and $\mathrm{COS}$ [Ito, 1993] and relatively short-lived gases such as DMS are good candidates, but it is most likely that a combination of the two is involved. Although the rate of oxidation of DMS in air is rather slow, around 12 days at polar latitudes [Berresheim et al., 1995], compared to $\approx 3$ days in more temperate latitudes [Hewitt and Davison, 1988], simple calculations suggest that this process is probably able to provide precursor products such as $\mathrm{SO}_{2}$ at a rate which is able to provide new particles and cause rapid changes in particle size by the heterogeneous growth mechanism. For example, the oxidation of $4 \mathrm{ng}$ (S) $\mathrm{m}^{-3}$ DMS (or $5 \%$ of the total DMS concentration typically found in maritime air) will provide sufficient mass to give a concentration of $1000 \mathrm{~cm}^{-3}$ new particles of diameter $20 \mathrm{~nm}$. Thus DMS oxidation may be able to explain the rapid changes in the particle number density observed.

\section{Conclusions}

The concentrations of DMS obtained during the cruise of the RRS Bransfield in this study were as anticipated, with maximum concentrations occurring in the vicinity of the Antarctic Peninsula and in the Weddell Sea. Methane sulfonic acid concentrations were also observed to be enhanced in the vicinity of the peninsula and in the Weddell Sea, with a mean in these areas of $103 \mathrm{ng} \mathrm{m}^{-3}$. Although broad agreement was seen between DMS and MSA concentrations, with maxima in both data sets observed in the same general areas, good correlation was not observed between individual data pairs, probably because of the different lifetimes of these species in the atmosphere. The ratio of MSA to nss $\mathrm{SO}_{4}{ }^{2-}$ was very low in areas north of $58^{\circ} \mathrm{S}$ but increased farther south. Unfortunately, no size-resolved data were available on the chemical composition of the aerosol because only bulk filter samples were collected.

Average accumulation mode aerosol concentration of 25 $\mathrm{cm}^{-3}$ were observed in marine and polar air masses south of $58^{\circ} \mathrm{S}$ along with a background $\mathrm{CN}$ concentration of between 400 and $600 \mathrm{~cm}^{-3}$. On many occasions, enhanced $\mathrm{CN}$ concentrations, of the order of $4000 \mathrm{~cm}^{-3}$, were observed and attributed to new particle formation in the marine boundary layer. These new particle formation events (or nucleation bursts) were observed to be strongly dependent on existing aerosol surface area and were more frequent in outflowing polar air masses over the broken pack ice in the Weddell Sea where DMS fluxes were high and polar aerosol surface area quite low. Results suggest that unless the nucleation bursts can be sustained for periods of more than a few hours, these newly formed particles are rapidly lost through coagulation processes and lead to only negligible enhancement of the background $\mathrm{CN}$ or $\mathrm{CCN}$ concentrations. It is suggested that the background $\mathrm{CN}$ concentration can be sustained by a particle formation rate or source strength of $26-58$ particles $\mathrm{cm}^{-3} \mathrm{~d}^{-1}$; however, it is not clear whether these particles are formed at a constant rate or by a high frequency of moderate nucleation events in the boundary layer or by other mechanisms such as free tropospheric entrainment. Simple calculations suggest that typical free troposphere $\mathrm{CN}$ concentrations are readily capable of providing a $\mathrm{CN}$ source of this strength.

Experimental efforts to illustrate a controlling link between DMS and $\mathrm{CCN}$ in the marine boundary layer have to date proved far from conclusive [Ayers and Gras, 1991; Putaud et al., 1993; Quinn et al., 1993; Lawrence, 1993]. Furthermore, theoretical studies into $\mathrm{CCN}$ formation from DMS lead to conflicting results [Russell et al., 1994; Lin et el., 1992; Chameides and Stelson, 1992; Raes and Van Dingenen, 1992]. The results presented in this study do not demonstrate any simple or clear link between DMS and aerosol nss sulfate.

Acknowledgments. We thank Captain Stuart Lawrence and the officers and crew of the RRS Bransfield for their help during the cruise and Eric Wolff, David Peel, Rob Mulvaney, and the logistical support staff of the British Antarctic Survey for their valuable discussions during all stages of this study and for their work in locating people and parts and arranging their transport to the ship. We also thank Joyce Harris at NOAA for help with air mass back trajectories. The work was made possible by the financial support of the Natural Environment Research Council (grant GR3/7777A).

\section{References}

Ayers, G. P., and J. L. Gras, Seasonal relationships between cloud condensation nuclei and aerosol methane sulphonate in marine air, Nature, 353, 834-835, 1991.

Baltensperger, U., H. W. Gaggeler, D. T. Jost, M. Emmenegger, and W. Nageli, Continuous background aerosol monitoring with the epiphaniometer, Atmos. Environ., 25A, 629-634, 1991.

Bates, T. S., R. J. Charlson, and R .H. Gammon, Evidence for the climatic role of marine biogenic sulfur, Nature, 329, 319-321, 1987.

Berresheim, H., Biogenic sulphur emissions from the sub-Antarctic and Antarctic oceans, J. Geophys. Res., 92, 13,245-13,262, 1987.

Berresheim, H., M.O. Andreae, G.P. Ayers, R.W. Gillett, J.T. Merrill, V.J. Davis, and W.L. Chameides, Airborne measurements of dimethylsulphide, sulfur dioxide, and aerosol ions over the Southern Ocean south of Australia, J. Atmos. Chem., 10, 341-370, 1990.

Berresheim, H., et al., DMS in the Antarctic Troposphere: First Results From Project "SCATE", XX General Assembly, Eur. Geophys. Soc., London, 1995.

Boeker, E., and R Van Grodelle, Environmental Physics, 193 pp., John Wiley, New York, 1995.

Bunt, J. S., Microalgae of the Antarctic pack ice zone, in Proceedings of the Symposium on Antarctic Oceanography, pp. 198-218, Sci. Comm. for Antarct. Res. (SCAR), Scott Polar Res. Inst., Cambridge, England, 1968.

Chameides, W.L., and A.W. Stelson, Aqueous phase chemical processes in deliquescent sea salt aerosols: A mechanism that couples the atmospheric cycles of $S$ and sea salt, $J$. Geophys. Res., 97, 20,565$20,580,1992$.

Charlson, R. J., J. E. Lovelock, M. O. Andreae, and S. G. Warren, Oceanic phytoplankton, atmospheric sulphur, cloud albedo and climate, Nature, 326, 655-661, 1987.

Charlson, R. J., S.E. Schwartz, J. M. Hales, R. D. Cass, J. A. Coakley Jr., J. E. Hansen, and D. J. Hofmann, Climate forcing by anthropogenic aerosols, Science, 255, 423-430, 1992.

Clarke, A.D., Equatorial convection as a source of tropospheric nuclei over the remote Pacific, in Dimethylsulphide: Oceans, Atmospheres, 
and Climate, edited by G. Restelli and G. Angeletti, pp. 323-330, Kluwer Acad., Norwell, Mass., 1992.

Coakley, J. A., Jr., R. D. Cass, and F. B. Yurevich, The effect of tropospheric aerosols on the earth's radiation budget: A parameterization for climate models, J. Atmos. Sci., 40, 116-138, 1983.

Cover, D. S., V. N. Kapustin, P. K. Quinn, and T. S. Bates, New particle formation in the marine boundary layer, J. Geophys. Res., 97, 20,581-20,589, 1992.

Davison, B. M., and A. G. Allen, A method for sampling of dimethylsulfide in polluted and remote marine atmospheres, Atmos. Environ., 28, 1721-1729, 1994.

Davison, B. M., and C.N. Hewitt, Natural sulphur species from the North Atlantic and their contribution to the United Kungdom sulphur budget J. Geophys. Res., 97, 2475-2488, 1992.

Davison, B. M., and C. N. Hewitt, Elucidation of the tropospheric reactions of biogenic sulfur species from a field measurement campaign in NW Scotland, Chemosphere, 28, 543-557, 1994.

Ferek, R. J., D. A. Hegg, J. A. Henning, and P. V. Hobbs, An improved filter pack technique for airborne measurements of low concentrations of $\mathrm{SO}_{2}$, J. Geophys. Res., 96, 22,373-22,378, 1991.

Fitzgerald, J. W., Marine aerosols, a review, Atmos. Environ., 25A, 533$545,1991$.

Fouquart, Y., and $\mathrm{H}$. Isaka, Sulfur emissions, $\mathrm{CCN}$, clouds and climate: $\mathrm{A}$ review, Ann. Geophys., 10, 462-471, 1992.

Gäggeler, H. W., U. Baltensperger, M. Emmenegger, D. T. Jost, A. Schmidt-Ott, P. Haller, and M. Hofmann, The epiphaniometer: A new device for continuous aerosol monitoring, J. Aerosol Sci., 20, 557564, 1989.

Goldan, P. D., W. C. Kuster, D. L. Albritton, and F. C. Fehsenfeld, The measurement of natural sulfur emissions from soils and vegetation: Three sites in the eastern United States revisited, J. Atmos. Chem., 5 439-467, 1987.

Gras, J. L., Condensation nucleus size distribution at Mawson, Antarctica: Seasonal cycle, Atmos. Environ., 27A, 1417-1425. 1993a.

Gras, J. L., Condensation nucleus size distribution at Mawson, Antarctica: Microphysics and chemistry, Almos. Environ., 27A, 14271434, 1993b.

Harvey, M. J., G. W. Fisher, I. S. Lechner, P. Isaac, N. E. Flower and A. L. Dick, Summertime aerosol measurements in the Ross Sea region of Antarctica, Atmos. Environ., 25A, 569-580, 1991.

Hegg, D. A., Heterogeneous production of cloud condensation nulcei in the marine atmosphere, Geophys. Res. Lett., 17, 1990.

Hewitt, C. N., and B. M. Davison. Review: The lifelimes of organosulphur compounds in the troposphere, Appl. Organometallic Chem, 2, 407-415, 1988.

Hoppel, W. A., and G. M. Frick, Evidence of particle formation by homogeneous nucleation over the oceans, in Lecture Notes in Physics, vol. 309, edited by P. E. Wagner and G. Vali, pp. 241-244, Springer-Verlag, New York, 1988.

Hoppel, W. A., and G. M. Frick, Submicron aerosol size distributions measured over the tropical and South Pacific, Atmos. Environ., 24A, $625-659,1990$

Hoppel W. A., G. M. Frick, and R. E. Larsen, The effect of nonprecipitating clouds on the aerosol size distribution in the marine boundary layer, Geophys. Res. Lett., 13, 125-128, 1986.

Hoppel, W. A., G. M. Frick, J. W. Fitzgerald, and R. E. Larsen, Marine boundary layer measurements of new particle formation and the effects of nonprecipitating clouds have on aerosol size distribution, $J$. Geophys. Res., 99, 14,443-14,459, 1994.

Ito, T., Size distribution of Antarctic submicron aerosols, Tellus, 45B, $145-159,1993$.

Jaeker-Voirol, A., and P. Mirabel, Heteromolecular nucleation in the sulphuric acid-water system, Atmos. Environ., 23A, 2053-2057, 1989.

Jennings, S. G., and C. D. O'Dowd, Volatility of aerosol at Mace Head, on the west coast of Ireland, J. Geophys. Res., 95, 13,937-13,948, 1990.

Jennings, S. G., C. D. O'Dowd, T. C. O'Connor, F. M. McGovern, Physical characteristics of the ambient aerosol at Mace Head, Atmos. Environ., 25A, 557-562, 1991.

Kirst, G. O., M. Wanzek, R. Haase, S. Rapsomanikis, S. DeMora, G. Schebeske, and M. O. Andreae. Ecophysiology of ice algae (Antarctica): Dimethylsulfoniopropionate content and release of dimethylsulfide during ice melt, in Dimethylsulfide: Oceans, Atmosphere and Climate, edited by G. Restelli and G. Angelette, Kluwer Acad., pp. 23-26, 1993.

Krebs, W. N., Ecology of neritic marine diatoms, Arthur Harbor. Antarctica, Micropaleontology, 29, 267-297, 1983.
Lawrence, M.G., An empirical analysis of the strength of the phytoplankton-dimethylsulfide-cloud-climate feedback cycle, J. Geophys. Res., 98, 20,663-20,673, 1993.

Leakey, R., Signy Phytoplankton, British Antarct. Surv., Cambridge, 1991.

Lin, X., W.L. Chameides, C.S. Kiang, A.W. Stelson, and H. Berresheım A model study of the formation of $\mathrm{CCN}$ in remote marine areas, $J$. Geophys. Res., 97, 18,161-18,171, 1992.

Liss, P. S., and P. G. Slater, Flux of gases across the air-sea interface, Nature, 247, 181-184, 1974

Luria, M., C. C. Van Valin, J. N. Galloway, W. C. Keenes, D. L.Wellmann, H. Sievering, and J. F. Boatman, The relationship between dimethyl sulphide and particulate sulfate in the mid-Atlantic Ocean atmosphere, Atmos. Environ., 23, 139-147, 1989.

O'Dowd, C.D. S. G. Jennings, M. H. Smith, and W. Cooke, A high temperature volatility technique for determination of atmospheric aerosol composition, J. Aerosol Sci., 23 (suppl, 1), S905-S908, 1992.

O'Dowd, C.D., and M. H. Smith, Physicochemical properties of accumulation mode aerosol over the N.E. Atlantic: Evidence for submicron wind-speed related sea salt aerosol production, $J$. Geophys. Res., 98, 1135-1149, 1993.

O'Dowd, C.D., M. H. Smith, and S. G. Jennings, Submicron particle, radon and sool carbon characteristics over the Northeast Atlantic, $J$. Geophys. Res., 98, 1123-1135, 1993.

Pandis, S. N., U. Baltensperger, J. K. Wolfenbarger, and J. H. Seinfeld, Inversion of aerosol data from the epiphaniometer, J. Aerosol Sci., 22, 417-428, 1991.

Putaud, J.-P., S. Belviso, B. C. Nguyen, and N. Mihalopoulos, Dimethylsulfide, aerosols and condensation nuclei over the tropical northeastern Atlantic Ocean, J. Geophys. Res., 98, 14,863-14,871, 1993.

Quinn, P. K., D. S. Covert, T. S. Bates, V. N. Kapustin, D. C. RamseyBell, and L. M. McInnes, Dimethylsulfide/cloud condensation nuclei/climate system: Relevant size-resolved measurements of the chemical and physical properties of almospheric aerosol particles, $J$. Geophys. Res., 98, 10,411-10,427, 1993.

Raes, F., Entrainment of free tropospheric aerosol as a regulating mechanism for cloud condensation nuclei in the remote marine boundary layer, J. Geophys. Res., 100, 2893-2903, 1995.

Raes, F., and R. Van Dingenen, Simulations of condensation and cloud condensation nuclei from biogenic $\mathrm{SO}_{2}$ in the remote marıne boundary layer, J. Geophys. Res., 97, 12,901-12,912, 1992.

Russell, L. M., S. N. Pandis, and J. H. Seinfeld, Aerosol production and growth in the marine boundary layer, J. Geophys. Res., 99, 20,98921,003, 1994.

Seinfeld, J.H., Atmospheric Chemistry and Air Pollution, John Wiley, New York, 1986.

Smith, M. H., I. E. Consterdine and P. M. Park, Atmospheric loadings of marine aerosol during a Hebridean cyclone, Q. J. R. Meteorol. Soc., IIS, 383-395, 1989.

Staubes, R., and H. W. Georgii, Biogenic sulfur compounds in sea-water and the atmosphere of the Antarctic region, Tellus, 45B, 127-137 1993.

Stull, R. B., An Introduction to Boundary Layer Meteorology, Kluwer Acad, Norwell, Mass., 1988.

Wayne, R. P., Chemistry of Atmospheres, 2nd ed., Oxford Sci., 1991.

Yin, F., D. Grosjean, and J. H. Seinfeld, Photooxidation of dimethyl sulphide and dimethyl disulphide, 1, Mechanism development, $J$. Atmos. Chem., 11, 309-364, 1990a.

Yin, F., D. Grosjean, R. C. Flagan, and J. H. Seinfeld, Photooxidation of dimethyl sulphide and dimethyl disulphide, 11, Mechanism evaluation, J. Atmos. Chem., 11, 365-399, 1990b.

U. Baltensperger and M. Schwikowski, Paul Scherrer Institut, $\mathrm{CH}$ 5232 Villigen PSI, Switzerland.

B. Davison and C. N. Hewitt (corresponding author), Institute of Environmental and Biological Sciences, Lancaster University, Lancaster, LA1 4YQ, United Kingdom. (e-mail: n.hewitt@lancaster.ac.uk)

C. D. O'Dowd, J. A. Lowe, and M. H. Smith, Department of Pure and Applied Physics, University of Manchester Institute of Science and Technology, PO Box 88, Manchester, M60 1QD, United Kingdom.

R. M. Harrison, Institute of Public and Environmental Health, University of Birmingham, Birmingham, B 15 2TT, United Kingdom.

(Received December 12, 1994; revised February 29, 1996;

accepted April 2, 1996.) 